\title{
The journal Biological Invasions evolves
}

\author{
Laura A. Meyerson (1) - Daniel Simberloff
}

Received: 8 October 2021 / Accepted: 17 October 2021 / Published online: 17 November 2021

(C) The Author(s), under exclusive licence to Springer Nature Switzerland AG 2021

Scientific and political consensus on the severity of biological invasions mounted during the 1980s when the Scientific Committee on Problems of the Environment (SCOPE) focused on the causes, impacts, and management of invasions. By the early 1990s, the conservation community was increasingly alarmed by the devastating consequences species invasions were wreaking on biological diversity. Included in the Rio Convention on Biological Diversity, Article $8 \mathrm{~h}$ committed signatory nations to prevent, control, and eradicate potentially harmful alien species. The first international meeting on invasive species in 1996 in Trondheim, Norway spawned an international partnership to combat species invasions the following year-the Global Invasive Species Programme (GISP). The inaugural issue of Biological Invasions arrived two years later at the tail end of the twentieth century, an era that saw exponential growth in international trade, transport, and travel and consequent introductions of non-native species across the globe.

L. A. Meyerson ( $₫)$

Department of Natural Resources Science, University of Rhode Island, Kingston, Rhode Island 02881, USA

e-mail: lameyerson@uri.edu

D. Simberloff

Department of Ecology and Evolutionary Biology, University of Tennessee, Knoxville, TN 37996, USA
Biological Invasions was launched in 1999 as a platform for "scholarly communication" of the invasion-associated "phenomena that have changed, and now are changing, the face of the Earth so dramatically" (Carlton 1999). The journal's 20 founding editors represented 10 countries and included only three women, but over the ensuing 22 years, the number of countries represented on the editorial board has more than doubled and the percentage of female editors has nearly tripled. Nonetheless, the increasing number of nationalities represented by editors of Biological Invasions is only a fraction of the everchanging source and recipient regions of invasive species. At this writing, editorial board members represent 21 countries while the journal has received submissions from 132 countries and has invited reviewers from 115 countries. To fulfill the initial goal of making the journal a "portal for research on the patterns and processes of invasions across the broadest menu..." (Carlton 1999), Biological Invasions must continue striving to increase geographic and demographic representation on its editorial board and in it pages. This is fair and will likely result in better papers overall.

Recognizing the "English tax" often suffered by authors from non-Anglophone countries and inspired by Black Lives Matter to ensure equal opportunity in Biological Invasions regardless of race, ethnicity, gender, or sexual orientation, the journal began a self- 
study in 2018 to examine available data on the diversity of our editorial board, authors, and reviewers. During this process, additional issues arose related to the use of gendered pronouns and inclusive name change policies. The results of this self-study follow in this issue. Kuebbing et al. (2021) present current and historical data on editorial board demography. Nuñez et al. (2021) report on the national affiliation of corresponding authors for manuscript submissions and acceptances from 1999 to 2021 and on reviewer countries of origin. Lieurance et al (2021) discuss retroactive changes to author names after a gender transition or taking a partner's name and using genderneutral language in editorial communications.

These efforts are a starting point to further diversify Biological Invasions both on our board and in the papers we publish. Furthermore, we hope that more geographic and cultural perspectives on the editorial board and among authors will lead to novel insights in invasion science and perhaps help to answer some of the stubborn questions that continue to elude us.

\section{References}

Carlton JT (1999) A journal of biological invasions. Biol Invasions $1: 1$

Kuebbing S, McCary MA, Lieurance D, Nuñez MA, Chiuffo MC, Zhang B, Seebens H, Simberloff D, Meyerson LA (2021) A self-study of editorial board diversity at Biological Invasions. Biol Invasions. https://doi.org/10.1007/ s10530-021-02664-8

Lieurance D, Kuebbing S, McCary MA, Nuñez MA (2021) Words matters: How to increase gender and LGBTQIA+ inclusivity at Biological Invasions. Biol Invasions. https:// doi.org/10.1007/s10530-021-02665-7

Nuñez MA, Chiuffo MC, Seebens H, Kuebbing S, McCary MA, Lieurance D, Zhang B, Simberloff D, Meyerson LA (2021) Two decades of data reveal that Biological Invasions needs to increase participation beyond North America, Europe, and Australasia. Biol Invasions. https://doi.org/10.1007/ s10530-021-02666-6

Publisher's Note Springer Nature remains neutral with regard to jurisdictional claims in published maps and institutional affiliations. 